\title{
MOGOL KANUNLAR
}

Yazan: Dr. iur. Kurt ALINGE

Çeviren: Prof. Dr. Coşun UÇOK

\section{Bölium}

\section{HUKUK KAYNAKLARI}

\section{Kesim}

\section{Cengiz Han ve ardgelenleri zamanundaki kaynaklar}

\section{§ 1. Cengix Han'un buìüuk yasa'si:}

(1) Cengiz Han tarafından siyasî bir birlik haline getirilinciye kadar her Moğol boyu yazlmamış örf ve âdet hukukuna göre yaşamakta idiler. Bu büyük fatih, kendisinin bir millet hâline soktuğu bu halka ilk yazılı hukuku da vendi; bu, Büyük Yasa (1) idi. Bu yasamm orijinal metni ele geçmemistir, ancak bunun bazı parçaları veya muhtevası hakkında bazl bilgiler arap ve iranh tarih yazarlarmm veya seyyahlarınm eserlerinde (aşağıya bakmız) bulunmaktadır; aymea Moğol kroniği Çindami-inErike'de, sonra Yüan sülâlesinin 1320 tarihli kanun mecmuasında ve Altınordu hanlarınin Yarliklarinda buna işaretler de vardır. Sayları oldukça çok olan bu vesikalar karşısında Yasa'nın müstekil yazll bir kanun olarak mevcut bulunduğundan șüphe etmek her hâlde yerinde değiỉdi* (2). Diğer taraftan elimize geçmiş bulunan parçaların, yasanın tamamını teskil etmiş olmaları da akla pek yokın gelmemektedir; zira buntarm bazlları doğrudan doğruya özet olduklar gibi diğerlerinin de hakikaten Yasa'dan alınmış olduklan şüpheyi uyandırmaktadır (3).

1) Yasa (veya Yasak) kanun demektir.

2) Bu hususa P. Popoff (bk, Riaz, S. 11, not 1.) itiraz etmekte ve eğer Yasa yazjlı kanun olsaydı Yüan - ch'ao Tien - chang (1320 tarihli, Yüan sülâlesi kanun mecmuası) a girmesi gerekirdi, hâlbuki bunda yalnız ụ̈ yerde Yasa hükümleri alınmıştır ki bunlardan da yalnız birisi Makrizi'deki fragmentlerden birisine uymaktadır (bk. S. 30), demektedir. Bana kalırsa Popoff'un bu iddiası Yüan - chao Tien - chang'ı yanlıs olarak, Mogolistan için çukarılmış hususî kanunlar mecmuası saymasından ileri gelmektedir (bk. II. Bölüm, I. Kesim, 3.).

3) Riaz.a göre (S. 11) Makrizi Yasa'nin tam metnini verdiğini iddia ediyormus. Chrestomathie arabe adlı kitabinm 2. cildinde Makrizi'nin metnini (S. 59 - 62) ve Fransızca tercitmesini (S. 160 - 163) veren de Sacy'de böyle bir iddiaya rastlıyamadım. Bunun için ayrica III. Bölüm, I. Kesim, önsözze bakunłz. 
Yasa'nın meydana gelişi hakkında, iranl tarih yazarı Raşid al-Din (ve buna benzemek üzere Misırl tarihçi Makrizi) Cengiz Han'ın VangHan'a (4) karşı kazandığ bir zaferden ve Mogol boylarn arasinda hakimiyetini kurduktan (1206) sonra 'tbuiyük bir meclis topladığını ve (zaferinin) iyi neticeler vermesi için iyi ve kuvvetli kanunlar yapılmasını emrettiğini" söyler (5). Moğol kroniği Çindami-in-Erike'ye göre ise o, Çin kanunlarını örnek olmaya lâylk olduklam kamısında bulunduğundan bix Çinli bilgini ve onun 18 ögrrencisini Yasa'nın yazılması ile görevlendir. mişti (6).

Eununla beraber bana kalırsa Yasa'nın hiçbir yerinde doğrudan doğruya bir Çin nüfuzunun mevcudiyeti ispat edilemez; ayrıca adı geçen Moğol kroniğinin iddiası da başka hiçbir yönden teyid edilmemiştir. Ancał - hiçbir kaynakta bu zikredilmemiş olmakla beraber - Cengiz'in kanunun hazırlanmasını, çok bilgili ve âlim sayılan ve kendisi tarafından geniş yetkilerle başyargıçlı̆̆a getirilmiş bulunan üvey kardeşi Şigi-Kutuku'ya emretmis olması mümkün gibi görünmektedir (7).

Kanunun metni (Makrizi'ye göre) hükümdarın emri üzerine çelik levhalara kazlld (8). Bütün Yasa'nın - bütün bugüne kadar ele geçmiş olup hakikîliklerinden şüphe edilmiyen parçalar da içine àlan bir şekilde (Bk. I. Ek ve III. Bölümün 1. kesiminin başlangıcina) - daha 1206 'da veya hemen biraz sonra hazırlanmıs olması ve hele söylenilen şekilde tespit edilmiş bulunması imktânsızdır. Zira o zamanlar, $1206 \mathrm{da}$, henïz belki Moğol'larca ancak adlam bilinen bazi kişi gruplarına 10 numaralı fragmentte tanınmıs olan vergi muafiyetinin ne mânası kalırdı? O zaman hangi Mogol, Alị bin Ełbu Talib'i, Kuran okuyucuları veya müezzinleri bilirdi? O zamanlar ne, kanun koyucuyu hayvan kesiminin yerli şekli ile islâmî şek-

4) Temuçin'in amcalarından 'biri ve Moğol boy beylerinden olan Toğrul Han'a, Tatarlara karşı yapmış olduğu başarılı yardımdan ötürü, Kuzey Çin'de hüküùn süren (Tunguz) Chin sülâlesinin hükümdar tarafindan "Wang Han, șeref unvanı verilmişti. Başlanģçta Temuçin'in müttefiki olduğu halde sonradan ona düşman kesildi ve onun tarafindan hakimiyeti elinden almd.

5) Riaz S. 10.

6) Riaz sayfa 10.

7) Hara - Davan S. 59. - Yüan-ch'ao Mi - Shih (Yïian'm gizli tarihli, rusçaya Palladiy tarafindan tereüme edilmiştir. S. 115) e göre Sigi - Kutuku'ya hatta kendi kararlarm da yarması emredilmişoniş. Belki de yaalı Yasanm baslangıcin bu kararlarm yazimaisı tegkill etmiştir. 
lini mukayeseye sevketmiş olabilirdi (8. fragment)? Bunun içindir ki Yasa'nun bütününü, ylliarca süren bir gelişmenin sonuct: ve Cengiz'in emri ile kendi tarafından veya onun adına verilmiş olan hükümlerin veya ihtiyaçlara göre çlkarılmıs olan emirlerin tespiti olarak kabul ediyorum. Böylece Yasa'nın her hükmü àyrı bir zamana aittir ve bu hükümler eski örf ve âdet hukukunun teyidi olmadikları hailerde Yasa'ya hakim olan ana fikire uygun oldukları nispette eskidirler (9).

Cengiz yalnız Moğolistan'da değil bütün ele geçirdiği üikkelerde $Y_{9}$. sa'smın yürürlükte olmasın istemiģti. Gene de, surf Moğol âdet ve görïislerine sıkı sıkıya bağı olan bazı hükümleri hâkimiyet altına alınmıs olan milletlere zorla kabul ettirme denemesine pratikde pek öyle ciddî olarak yer verilmemiştir. Zaten bu, her ne kadar bu yolda bazı ' münferit olaylar biliniyorsa da, pek güç uygulanabilirdi (10).

Yasa'nın Moğollarda da ne kadar zaman yürürlükte kalmış olduğunu bilmiyoruz. Ancak meydana getişini en geç XVI. Yüzyll'm birinci yarısında kabul edebileceğimiz (Bk. II. Bölüm, 2, Kesim) "Eski TsaayinBiçik" in önümïzze, halkın hukuk hayatının bazı bakımlardan oldukça değismiş bir manzarasım - her nekadar tam değilse de - sermesi vakıası Yasa'nın bundan çok önce unutulmuş olduğunu ispat etmektedir.

Buna karşlılk yürürlükte bulunduğu sıralarda yasianın görmüş olduğu saygı olaganüstï idi. Makrizi bu yolda şöyle demektedir (de Sacy $\mathrm{S}$. $163 \mathrm{v}$. öt.) : "ölümü (Cengiz'in)nden sonra çocuklarn ve onlamn çocuklarl, ilk Müslümanlar nasıl Kuran'n hükümlerine uymaya çalışmışlarsa ay-

8) De Sacy S.160, . Eğer bu doğru ise o zaman Uygur yazısı kullanılmı olmalıdır. Çünkü Moğollar ilk defa olarak Kubilây zamannnda bir yazıya sahip olabilmişlerdir. - Yasa sonradan başka bir şekilde de başlı başına yazlıp tespit edilmişe benzemektedir; çünkü Makrizi (de Sacy S. 161) bir (adı da bildirilen) memurun Yasa'nin bir nüshasunı (etraflica bildiren) bir medresenin kütüphanesinde Bağdat'da görmüuş olduğunu kendisine anlatmış olduğunu bildirmektedir. - Ne yazık ki Makrizi kendisi Yasa'yı nereden aldığnn bildirmemektedir. -

9) D'Ohsson'a göre (S. 415 2. Not) Raşid al - Din'deki bir yerden Yasa'nın Cengiz Han İran'dan döndükten sonra yanı 1225 de yazilmış olduğu anlaşılmakta imiş.

10) Bunun için bk. Carpini'nin Risch tercümesine, S. 184, 3. Not. - Makrizi, savas esirlerinin ardgelenleri olup Mısır ve Suriye'de oldukça çok sayıda bulunan Moğollar'ın İslâmiyeti kabul ettikten sonra bile Yasa'nun kaidelerine uygun bir şekilde yaşadıklarını iddia etmektedir. Hatta bunlar aralarındaki hukukî anlaşmazlıkları halletmek için Yasa'nın hükümlerine uygun kararlax veren' ("Conformément aux lois du yasa", de Sacy S. 165) ve "Hacib, denilen özel yargiçlara baş vururlarmış. Eğer bu doğru ise, gene de Yasa'nın bütününe uyulduğu düşünülemez, zira İslâmiyeti kabul etmiş olan Moğollar'ın gözlerinden, Yasa'nın birçok isteklerinin Kuran'dakilerle telif kabul etmiyeceği kaçmamıs olmalıdır. 
nı dakiklikle Yasa'nın enirlerini yerine getirmişlerdir. Bu onlar için bir nevi din mahiyetinde idi ve bunlardan birinin Yasa'ya aykım hareket etmiş olduklar biiinmemektedir."

Cengiz Hanın ve ardgelenlerinin devletleri bakımından Yasa'nın önemi ne kadar yüksek tutulsa yeridir. Onun cemir gibi hükümleri ile ulustn birliği korunabiimiş, sükûn ve intizam temin edilmiş ve böylece eşsiz fetihler için gereken önşartlar ortaya konulmuştur.

(II) Yasa hakkında en önemli kaynaklar şunlardir:

(1) Alâ al-Din, XIII. Yüzyıl tranlı tarih yazariarından; "Tarih-i Cihanküşa" ("Dünya fatihinin tarihi") adl eserinde 1217-1257'ye kadar Moğollar'ın tarihini anlatmakta ve birçok yerlerde Yass'ya işarette bulunmaktadır; bu eser Mengï Han (Munke Han) in Karakurum'daki saraynda bizzat yaşamış olup (1252) Hüiàgû zamanında 20 yıl Bağdat valiliğinde bulunmuş olan bir çağdaşın eseri olduğundan çok değerlidir;

(2) Raşid al-Din (Fazl al-Allah), XIII. XIV. Yüzyl tranlı tarih y2zarlarından; "Cami al-Tevarih" adlı eserinin ilk cildinde (Hicrî 702=M. 1303'de yazlimıştır) bugiun artık kaybolmuş bulunan Moğol kaynaklerına dayanarak ve Çin, Hind, Uygur bilginlerinden ve diğer bilginlerden faydalanarak ve Iran hükümdarlarından Sultan Gazan Hanın emri üzerine yazmış olduğu Moğollar'ın ilk tarihi hakkındaki bahisler bulunmaktadır (Bu Quatremère tarafindan tercüme edilmiştir: Histoire des Mongols de la Perse par Rashid-Eddin, Paris 1836);

(3) Ibn-Batuta, XIV. Yüzyll Arab seyyahı ("Voyages", texte arabe et trađuction par Défrémery et Sanguinetti, 4 cild. Paris 1874 v. öt.);

(4) Makrizi (Taki al-din Ahmed al-Makrizi), XV. Yüzyl Mısır!ı tarih yazarn; "Kitab al-muvaiz v'al-itibar" (Misır'ın tasviri) adll eserinin "Hacib" bölümünde Yasa fragmentlerinin büvük bir kısm" (Nu. 1-26) bulunmaktadur; bk. do Sacy, Chrestomathie arabe, arabca metin S. 59-62, fransizca tercümesi $S$. 160-163;

(5) Mirhond (Muhammed, Hanvend-Sah'm oğlu), XV. Yüzyll tran!1 Tarih yazam; "Ravzat al-safa" adl dünya tarihine ait eserinin beşinc: cildinde Cengiz Han'ın ve ardgelenlerin tarihini anlatmaktadır (daha çok "Cami al-tavarih" ve diğer Iran kaynaklarından faydalanmıştır).

Ele geçmiş olup hepsi hakikî olarak kabul edilmemiş bulunan 36 Yasa fragmentinin türkçeleri bu yazını 1 numaralı ekinde bulunmaktadır. Bu fragmentler ancak kaynaklarda Yasa'dan alınmış oldukları açıça bil_ dirilmis olan fragmentlerdir.

Buna karşılık Pétis de La Croix'nın, Histoire de Grand Genghizcan Premier Empereur des Anciens Mongols (Paris 1710) adli eserinde "Yas. sa Genghizcani” adı altında bizim Yasa ile hiçbir ilgisi bulunmıyan ve 
müellifin Plano Carpini, Rubruk, Marco Polo gibi kimselerin eserierinden yapmış olduğu bir kompilâsyondan başka bir sey olmıyan bir Yasa bulunmaktadır. Ayrica Makrizi gibi önemli bir kaynakdan da müeliifin haberi olmadığı anlaşılmaktadır. Bununla beraber Pétis de La Croix'nın bu "Yassa"sı hiç bir tenkide tâbi tutulmaksızın Harold Lamb tarafindan, birçols baskıları yapılmıs olan (oldukça edebî) "Gengis Khan, Emperor of all Men" (New York) 1928) adlı eserine alınmıştır; bundan da aynı seyi Khara-Davan (Bibliyografyaya bk.) almıştır; gene aynı kaynakdan Gibbon'un bile History of the decline and fall of the Roman Empire adil eserinin 64. bölümünde faydälandığı anlaşılmaktadır. Daha yeni ve ciddî müelliflerden Dr. L. Wieger S. J, da "Sommaire du Yassa" (Histoire modern de ia Chine, S. 1918 v. öt.) sinda aynı kaynalstan faydalanmisțtır, 1.2 .18

\section{2. Diğer Kaynalłdar 1:}

Eski kaynaklardan Cengiz Han'in ve ardgelenlerinin imparatorluğundaki hukuk hakkında öğrendiklerimiz bu kaynaklarn ozamanki savaş olayları, Moğollar'ın âdet ve yaşama tarzlam vs. hakkında verdikieri etraflı bilginin yanında pek az bir yer tutmaktadır.

En önemli kaynak olarak iki fransisken papazın aşağıdaki eserleri anilmak gerekir :

(1) Johannes de Plano Carpini'nin "Historia Mongolarum" adlı eseri (lâtince metni Beazley yayınlamığtır, almancaya tercümesi Risch tarafindan yapılmıştır, bibliyografyaya blk.); bu müellif Papa IV. Innosens'in elgisi olarak 1245 de Mogolistan'a gitmiş, 1246 da Karakurum'a varmıs, Kuyul'un seçiminde ve taç giymesinde bulunmuş, Kasımda dönüş yoluna çıımış ve bir yl sonra Lyon'da Papa'ya ulaşmıştır;

(2) Wilhelm von Rubruk'un "Ittinerarium ad partes orientales" adlı eseri (lâtince metni Beazley yayınlamıştır, almancaya tercümesi Herbst tarafindan yapılmıştır, bibliyografyaya bk.); Rubruk Fransa kuralı Saint-Louis'nin tavsiyenamesi ile 1252 Mayısında İstanbul'dan yola çlktı ve Arahk sonlarına doğru Mengü (Munke) Han'ın karargâhına vardı ve onun peșinden 1253 Paskalyasına doğru Karakurum'a gitti; seyahatinin gayesi Moğollar arasında misyonerlik yapmaktı, bu gayesine erişemedi ve 1254 yazinda Mengü'nün emri üzerine geriye dönmeye meclbur kaldı ve Ağustos 1255 te kendi manastırı olan Saint Jean d'Acre manasturina vard.

Her iki eser, iki iyi çağdaş müşahidin kendi gözleriyle gördüklerini objektif ve berrak olarak anlattıkları eserler olmak bakımından değerlidirler. 
Bizim lronumuz balkmmindan ikinci derecede önemli olan bir şey de Cengiz hian'ın Raşid a!-Din'in kaydetmiş olduğu sözleri (11) ile Kuyuk Han'm ve Batu'nun gene orada göndüğtumüz birer sözleridir. Cengiz Han'In sözleri daha çok hayat hakkında hakimâne ifadelerdir; bununla beraber bun': $\Omega$, Cengiz'in düşünüş tarzı ve karakterini biraz ayđunlatmaktadir, ama bunlarm konumuz bakumindan pek değeri yoktur. Kuyuk ve Batu'nun sözleri de her ne kadar oldukça genel mahiyette ise de, bunlardan birisi, Cengiz'in hemen ardından is başna gelenler zamanında da hükü̈m süren bükülmez disiplini, diğeri de Yasa'ya uyulmanın ne kadar cìddiye alındığinı gôstendiğinden buraya yaznlmıştır:

(a) Kuyuk Han: "Moğollar'ın vazifeleri şunlardır: Irademi yerine getirmek; ben çağırınca gelmek, emrettiğim yere gitmek, kimin adını söylemisssem onu öldürmek."

(b) Batu: "Yasa'ya aykım hareket eden herkes kafasın kaybeder".

\section{\& 3. 1320 tarihli Yüan Kanununun Moğol hukuku tbakmmından önemt}

Kendinden önçeki stullâlelerin örneklerine uyarak Yüan sülâlesi de Cin için kanunlar çkartmıştır. Bunlardan üçï zamanımıza kadar gelebilmişlerdir (12). Bunlardan da birisinin, Yüan-ch'ao Tien-chang (Yüan sülâle sinin kanun mecmuası) on Moğolistan için hazırlanmış özel bir kanun mecmuasi olduğu $P$. Popoff (bk. 2 numaral nota) tarafından idjia edilmiştir. Ĕger bu doğru ise, o zaman bu kanunun da, Moğol kanunu olmak dolaysiyle, bu eserin çerçevesi içinde incelenmesi gerekir. Bundan ötürü adı geçen kanun mecmuasının konumuz baksmından değerinin ne olduğunu araştırmamiz gerekmektedir.

Popoff bir kere kanun mecmuasının bir çok çineeye uymavan ve moğolcaya kaçan cümle kuruluşlariyle moğolcadan tercüme edilmiş olduğu hissini uyandırdığını söylïyor; Hyakinth' (13) in sehadeti de yer bak1mindan sinırlandimlmıs bir kanunun balhis konusu olduğunu göstermektedir ve nihayet bir kaç yl içinde (bok. 12. numarall not) büttiun ülkede yü-

11) Hepsi 29. bk. Riaz S. 15 v. öt.

12) Bahse konu olan su üs kanun kitabıdır:

1) Yüan - ch'ao Tien - chang (Yüan sülâlesinin 1320 de çılkarttı̆̆ kanun kitabı).

2) Yüan Tuug - chih (büyüik Yüan'larmn 1323 tarihli genel kanunlarn).

3) Chih - Yüan Hsin - Kê (Chih - Yüan (1321 - 1322) hükâmeti șrasundakj yeni kararnameler).

13) Hyakinth, haturalar 2. cild S. 190 da Imparator Ying - tsung (Moğolcasi Sodibala, $1320-23)$ un hükûmeti hakkunda şunlari yamaktadir Bu sırada îlkedeki kanun ve müesseseler henùz bir birlik göstermiyordu; Sodibala bundan ötürü 1323 de "Genel," adım verdiği yeni bir kanun kitabı çıkarttı (Bk. 12. Not. Nu.2.) 
rürlükte olacak üç aym kanunun çlkarlmıs olması da pek akla yalin gelmez, diyor.

Ancak bu kanun mecmuasınm kuruluşuna bir göz atmak bile Popoff'un iddiasının doğru olmadığına yetmekte ve hele kanunun içindekilerin incelenmesi ve daha sonraki saf Çin kanun mecmualariyle karşlaştımlması bu iddiayı büsjütün çürütmektedir. Kanun 373 maddeiden meydana gelen on balb'a ayrlmiktadır. 1-6. Lablar her bakanhğın yetkilarine ayrimıștır. Bu bakanlıklar şunlardır: (1) Rüitbeler bakanlıs̆ı, (2) Maliye bakanlığı, (3) Teşrifat bakanlığı, (4) Savaş bakanlığ1, (5) Ceza adaletj bakanlığı, (6) Bayındırlı ibakanlığı; geriye kalan dört bab hir ek karakteri taşımaktadır. Bunlar şu bahislere aymlmıstır: (7) Yüan imparatoriamnın emirnameleri, (8) hakimâne hükümet tasarrufları, (9) genel mahiyette hükûmet karamameleri, (10) ceza uculünün (iddia ve temyiz) ve devlet murakabesinin esaslar. Kanunun bu bünyesi bile önïmüzde sırf Moğolis tan jçin hazırlanmıs bir kanun mecmuası bulunduğundan süphe etmeye yeter de artar bile; çünkü bakanliklar tamamiyle eskiden kalma, Moğol sülâlesi tarafundan olduğu gibi alınmıs, Çin'in sosyal durumuna göre meydana getirilmiş devlet müesseseleri idiler. Ayrıca iptidaî göçebelerin ihtiyaçlarını karşlaması gereken kaidelerin yüksek bir gelişme seviyesine ulaşmış bir kültürün müesseselerine göre tasnif edilmiş olmalam da pek akla yakın gelmez. Bundan baska kaidelerin bir kısmı Moğol hukukunun hiç değişmemiş olan anlayıs tarzana taban tabana zit düşmekte, buna karşıllk Çin hukukunun esaslarnna da tıpa tıp uymaktadir. Böylece meselâ kızlığın bulunmamasının boşamaya hak vermesi, aymı soy admı taşıyan aileler arasında evlenmenin (14) veya memurların kızlarmı maiyetindeki kimselerle evlendirmelerinin yasak olması Moğol hukukiyle telif kabul etmediği halde Çin hukukunun karakteristik vasıflarındandır. Gene bunun gibi kardes karisı ile evlenme (15) veya memur dullarnin yeniden evlenmeleri yasağı da Mošol hukuku anlayışna yothanc1, Çin hukuk anlayışına ise uytgundur. Aymca 5. babda görülen ve Cin hukukunun mümeyyiz vasıflarından olup basit göcebe hayatı balsmından anlaşllması mümkün olm:yan hırs:zlığın muhtelif cinsleri, dolandırıcılık, irtikâp, sahtekârlık arasında fark gözetmek ve adî katil ile taammüdlü katil arasinda ayrumlar yapmak acaba niçin bu kanuna girmistir? Hele 6 . babada görülen dokumacllk hakkındaki kaideler ile gemicilik hakkındaki kaidelerin ne küiçük zanaat, ne de gemi tsliyen irmakları bilmiyen bir millet

14) Aynı soy adını taşıyan bütün kişilerin müşterek bir atadan geldikleri faraziyesine uygun olarak.

15) Bunun tamamen aksine Moğol hukuku Levirat evlenmesini mecburî kılmaktadir (bk. aşağıđa aile hukuku ve miras habsine). 
için konulmuş olmasını anlamak daha da güçtür. Nihayet düşünülürse kỉ, ta T'ang sülâlesinden (M. S. 654) beri her Çin sülâlesi kendi öz kanununu çlkartmış ve bu kanun mecmuaları böylece, her sülâle kendinden önceki sülâlenin kanunlannı da alıp kabul ettiğinden (16) şaşllacak bir devamlılık göstermiştir. Oyleki biz bugün sonuncu sülâle olan Ta-Ch'ing sülâlesinin kanunu olup 7 kısma aymlan (bu kısımlardan birincisi bir nevi "Umumî hükümler" teşkil etmektedir) Ta-Ch'ing-Lü-Li'nin 2.-7. kı sımlarında Yüan-ch'ao Tien-chang'in ilk altı (esas-) kısmin tekrar görüp tamyabilmekteyiz. Böylece de konuyu teşkil eden kanunun Moğolistan için değil de Çin için hazırlanmış bir kanun olduğundan artık şüphe edilemez.

Bu bahsi kapatırken ayrica söyliyelim ki. yukarda Yưan kanunundan verilmiş olan aile hukukuna ait misâllerin hepsi saf Çin kanunu olan Ta-Ch'ing-Lì-Li'de de aynen bulunmaktadırlar. O hâlde nasıl olur da Moğol Yüan sülâlesi kendi anayurdu için yabancı bir özel hukuku zoria uygulamak istemiş olur? Kaldı ki, sonradan hâkimiyeti ele geçirmiş olan Mançu Ta-Ch'ing sülâlesi bile orada eski* Moğol hulkukunu yürürlükte bırakmiștır.

Bunlardan ötürü 1320 tarihli Yüan kanununun Çir için çıarılmiş olup Moğolisatn için aym bir hukuku ihtiva etmediği artık șüphe edilmiyecek bir sekilde anlaşılmıştır. Bu bakımdan bu kanundian bu incelemede ayrica bahsedilmiyecektir.

16) Romals Praetor'un edictum'una dikkate değer bir benxeyis. Ancak Praetor, öngdeni tarafindan konulmus olan actiones ve exceptiones'leri muhafaza edip et-. memekte yainz ve yalniz bumlarm gayeye uygun gelip gelmemelerine baktıja hilde, eskiden kalan hukukun her sülale tarafmdan kabul edilmesi sebebi çin-

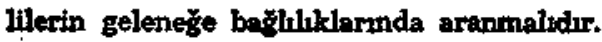




\section{Kesion}

\section{ESKI TSAAYTN BiÇIK}

Yalnız Palias'in bahsettiği (I. Bölüm, S. 193 v. öt.) Moğol kanunu "Tsaayin Biçik" (1) in meydana gelişi, muhtevası ve yürürlükde bulunduğu bölge karanlıklar içine gömülüdür. Orijinal metin ele geçmemiştir; yalnız adı geçen bilginin zikrettiği sekiz fragment bilinmektedir. Gene de bu sekiz fragment Yasa'dan soura Mogollar'ın hukukî hayatında meydana gelmiş olan değişiklikler hakkında bizi aydınlıtmaları bakımmdan dikkate değerler; aymca bunların birincisi, bu kanun mecmuasının meydana geliş zamanı bakımından bir dayanak oimak istidadını da göstermektedir.

Pallas bu Tasaayin Biçik hakkmnda "her nekadar artık uygulanmlyorsa da (Cengiz Han'dan beri) en eski kanundur ve her haide içinde ba* zl dikkate sayan hususlar bulunmaktadur" demektedir (S. 193). Kendisi Batı-Moğolları ve Kalumklar arasında incel̃emelerde bulunduğu sıralarda (1770 civarı) vürürlükte olan kanun olarak da 1640 tarihli (bk. III. Ek.) kanunu gösterdiğinden Tsaayin Biçik'in meydana getirilişi bu ylldan önce olmalıdır. Bu bakımdan bizi birinci fragment daha da aydınlatmaktadır. Bunda "rahiplerin" metresleriyle cinsî münasebette bulunmanin cezalandirlmaması bildirilmeketdir. Lamaizmanı XVI. yüzylın ikinei yarısında Moğolistan'a girmis olduğu, lamaizmanın rahiplerine ciddi bir şekilde imsâki şart koşmus olduğu ve 1640 tarihli kanunun hiçbir yerinde rahiplerin metreslerinden bahsedilmediği gibi rahip sınıfının çok iyi bir muameleye tâbi tutulduğu ve aymca hukukî himaye ile çevrili olduğu düşüüülürse, 1. fragmentin (ve böylece bütün kanunun) Lamaizmanın ülkeye girmesinden önceki bir zamanda yani en geç XVI. Yüzyılı!n ikinci yarısında kaleme alınmış olduğu kendiliğinden anlaşılır.

Tsaayin-Biçik'in - Yasa ve 1640 tarihli kanun gibi - siyasî bakımdar bir birleşmenin sonucu olduğu akla yakın gelmektedir. Bu siyasî birleșme Batı - Moğollarının birileşmeleri olaibilir. Böylece o zaman dört Batı - Moğol boyunun birlik kurdukları XIV. yüzyılın sonu da bunun meydana çıış tarihi olur (2).

Bu kanunun Batı-Moğolları arasında yürïurlükte olduğu kesin olarak bilinmektedir, zira Pallas bu husustaki bilgisini onlardan elde etmis-

1) Tsaayin - :Biçik "Yargılar kitabl, demektir, - Buna, müdevvinleri tarafundan gene, Tsaayin - Biçik adı verilmiş olan 1640 tarihli Oyrat - Moğol kanunundan ayurtedilebilmesi için "Eski," Tsaayin - Biçik adını verdik.

2) Bunu Leontivich iddia etmektedir, bk. Riaz S. 36 v. öt. 
tir. Bunun Halha'da da yürürïĭge girmiiş olduğunu kabul etmek, Batı ve Kuzey - Moğollan arasında hülküm süren düşmanlık karşısında hemen hemen imkânsizdır.

Bu kanun en geç 1640 tarihli kanunun yürürlìğe girmesiyle değerini kayıp etmis olmalıdır.

Ele geçen parçalamn metinieri (Pallas'dan alınmış, tarafımdan nımaralandırılmıştır) II. Ekde bulunmaktadır. 


\section{Kesim}

\section{TARIHLI IOYRAT — MOGOL KANUNU (YENI TSAAYIN BIÇIK)}

Bu kanunun meydana geliş tarihi yukarda (Cilt IX. Sayı 3-4, S. 244.) anlatılmıştı: Eski Tsaayin - Biçik gibi bu kanun da her hâlde zamanın intiyaçlarmdan meydana gelmiştir. 44 boyun bir birlił kurmak yolund:t yaptıkları anlaşmayla doğrudan doğruya ilgili olarak bunlarn bir arada kalmalarma hizmet edecek, içerdeki huzursuzluğu venecek ve dışdaki düsmanları savmaya yardım edecekti.

Kanunun giriş kısmından da anlaşılăğı gibi (1) bu kanun Halha, Cungaristan, Kuku-Nor, (Moğollar'ın oturdukları) Tibet, Batı Sibirya. Ural ve Volga bozkırlarında yürürlükte olacaktı. Buna karşliı Iȩ-Moğolistan'da yürürlükte olmıyacaktı. Bu kanunun Halha Moğolları üikesinde tam yürürrlüğe girmiş olup olmadığı șüpheyi uyandırakilir: kanunun terminologisi batı-moğoi - kalmukçadır; bundan başka ozamanlar Halaha'hların kendi yazılı kanunları vardı (Yedi Hoşun kanunu, bk. 4. Kesim, 1. not): bundan ötürü her hâlde 1640 tarihli kanun boylar arasindaki münasebetleri düzenlediği nispette bunlarda yürürlük kazanmıștır. Böylece bu kanun daha çok Batı-Moğol-Kalmuk kanunu olarał gözükmektedir.

Bu kanunun ne kadar zaman yürürlükte kalmış olduğunu bilmiyo. ruz. Palias (I. Bölürr, S. 194) onun XVIII. Yüzyılın sonunda bile Batı Moğollar'mda hala yürürlükte olduğunu görmüștür. Halha'da ise - eğer orada bütünü yürürlüğe girmiş olsa bile - en geç XVIIr. Yüzyılın başında Halha - Cirom (bk. 4. Kesim) tarafından yeri alınmış olmalıdır (2),

Her ne olursa olsuin 1640 tarihli bu kanun bizim özel ilgimize hak kazanmaktadır; çünkü o şimdiye kadar tam olarak ele geçen ve tercüms edilmiş olan biricik Moğol kanun mecmuasıdrr. Aymca onun büyük kısmi eski Moğol örf ve âdet hukukunu içine aỉmakta ve böylece bu hukuku ögrenebilmemiz için șimdilik on önemli kaynağı teşlkil etmektedir. $O$ zamanlar artık tamamiyle unutulmuş olan Yasa'nın izlerini onun içinde aramak beyhudedir. Ancak Eski Tsaayin-Biçik in bazı hükümlerinin bunun içine girmiş oiması kabul edilebilir; çünkü Tsaayin-Biçik bir Oyrat

1) Bizim konumuz bakumindan önemsiz olan girişi tercime etmedim (bk. II. ek). Bu, budist azizlerin uzun uzun sayllmasından sonra bu anlaşmayı imza eden 44 boy beyinin adlarm ihtiva etmektedir.

2) Donduk - Daşı Han (1758 civarı) tarafından çıkarılmış olan bir ek kanunla oldukça genişletildikten sonra bu kanun Rus hakimiyeti altındaki Kolmulklar'da 1822 ye kadar yiirirituikte kalmıştır. 
kanunu idi ve Oyratlar (Batur Han) 1640 tarihli kanunun tespitinde üstïn bir durumda idiler.

Bu Oyrat - Moğol kanununa Batur Han'ın oğlu meșhur Galdan belki de 1678 sıralarında (hükümetinin başında) iki ek çlkartmıştır.

Kanunun Moğolca (kalmukça) metni Golstunsky tarafindan "Mogol-Oyrat kanunları" adı altında ST. Petersburg'da 1880 yılında yayın- . lanmıştır (Rusça). Kanun Pallas tarafından (I. Bölüm. S. 194 v. öt) tercüme edilmiştir, aymca Leontoviç, Golstunsky ve başkaları tarafından da rusçaya tercüme edilmiştir (fazla bilgi için bk. Riaz S. 42). Ben III. Ekde Pallas dan aldığım metni yeni ifade tarzına uygun olarak ve materiel s1rasına göre vermekteyim; aymca Pallas'da bulunmiyan bazı hükümler de Riaz-Golstunsky'den alınmıştır (Riaz S. 46 v. öt; bk. III. ekdeki nota), 


\section{Kesim}

\section{HALHA - OROM}

Yalnız Kuzey Moğolistan'da (Halha'da) yürürlüğe girmek üzere nazrrianmış olan kanunlardan bildiğimiz bir tek kaynak (1) varưr kı o da Halha-Cirom'dur (2). Fanî gözlerden yüzyıllarca saklı (3) tutulan bu kanunun belki de biricik yazma nushası ilk olarak 1914 yllinda Prof. Jamtsarano (4) tarafindan Urga Hutuhtu'sunun Sandzotba (5) sinm bir Yamen inde Kiachta dolaylarında tbingol ırmağı kıyısında bulunmuş ve bundan kopya edilen bir nusha Petersburg'daki tlimler Akademisi müzo. sine gönderilmiştir. Bundan sonra kanun iki defa daha kopya edilmis ve bundan sonra da Jamtsarano ve Turunoff bu kanun mecmuasint tasvir etmişlerdir (6). Herhalde oldukça geniş tutulmuş olan bu eserin henüz bir tercümesi mevcut değildir. Ancak daha çok bab başilkların in verilmesiyle meydana çımıs olan bir muhtevaya bakıs meveuttur.

Eser sekiz bölüme ve bir eke ayrilmaktadır. Ilk yedi bölüm, Han'mn başkanlığnnda 'Tuşetukan Aymakk'ının Moğolları tarafından, adı geçen ijilginin görüşüne göre, 1709 yllunda tedvin edilmiştir. Bundan başka birinci bölümde Hovaraki (rahipler) hakkında ve her halde 1746 yllinda araya sıkıştırılmış bir kısım mevcuttu;. Sekizinci bölüm $1718^{\prime} \mathrm{de}$ ek ise

1) Belki de daha önce bir "Yedi Hoşunlar kanunu, adı altında bir kanun mecmuası vardı. Gerestsenze ülkeyi yedi oğlu araşında bölüştürerek yedi Hoşun'a ayırmışıı (Bk. aynı dergi C. IX. Sayı 3-4. S. 243); Halha - Cirom'un bir yerinde "Önceleri Yedi Hoşun tarafindan emredilmiş olduğu gibì, Hutuhtu'ya seyahatleri sırasında sinirsız olarak nakil vasitası ve yiyecek tahsis edilmelidir, denilmektedir. Başka bir yerde de gene "eski kanun, göz önünde tutulmuştur. Bununla beraber adı geçen kanun ele henüz geçmemiştir (BK. Riaz S. 70).

2) Cirom "kaide," "kararname, anlamina gelmektedir.

3) Moğollar'da kanun, onu uygulayacak olanların sırrı sayılırdt. Meselâ Maiski S. 286) Özerk Moğolistan hükûmeti (Bogdo - Gegen bölgesi) tarafindan 1919 da - 64 cild halinde - hazırlanmış olan (bununla beraber hị̧ bir zaman yürürriüğe giremiyen) kanunun bile çok gizli tutulduğunu bildirmektedir.

4) Profesör Jamtsaran̨o tanınmuş bir Mongololog (Buryat) olup ynllardan beri Ulan - Bator - Hoto (Urga) da Moğol Halk cumhuriyetinin ilim komitesinin sekreterliğini yapmaktadur.

5) Bk. Aynı dergi IX. cild, Sayı 3-4 S. 255.

6) Ts. Jamtsarano ve A. Turunoff, Halha - Cirom (İrkutsk Devlet Üniversitesi Profesör ve ögretmenlerinin çalışmaları mecmuasında, Cild. 6. Ruş̧a). 
Tsetsenhan Aymak Moğollar'ının yardımlarıyla 1736 veya 1796 (7) da meydana getirilmiştir.

Halha - Cirom'un tedvini sebebleri hakkında hiçbir yak:n bilgimiz yoktur. Ancak gerek Oyrat - Moğol kanunumda gerek eski Tsaayin - Biçik'de olduğu gibi bunda da her hâlde zamanı gösterdiği ihtiyaç buna sebeb olmuştur. Çünkü bilhassa asıl bölümier Kuzey Moğolistan'm iç bakımdan en karma karışk olduğu bir devirde meydana getirilm:ştir. Galdan'm ordulam ülkeyi görülmemiş bir şekilde tahrip etmişlerdi; halkın büyük bir kısmı kuzey veya gïneye kaçmıştı, eşk̛̂̂ya çetøleri her türlü ulaştırmayı tehdit ediyorlardı; bu sırada mançuryalı hami ise korkulan Çungar'laria hâlâ müthiş bir mücadelenin içinde bulunuyordu. Böyle bir durumda kanunla intizam ve sükûnu temin edip ülkeyi yeni bir yükselişe doğru setvketmek yolunda çalışmaktan başka ne akla gelebilir? Her ne kadar tam muhtevalam bilinmiyorsa da hükümlerden bir çoğunun bașliklar bile bu istikameti işaret etmektedir: ülkeye giriş müsaadesinin alınması ve hüviyet varakası çlkartmak mecburiyeti, seyahat için resmî müsaade (bk. Ek. IV. F 1-4), askerî kanunlar (Ek IV. G) vsr, gibi,

Kanunun giriş kısmından da anlaşıldığa gibi Halha. Cirom bütün Ku. zey Moğolistan'da yürürlüğe girmek üzere hazırlanmıştır. Giriş'de arkadan gelen kaidelerden "Ụ̧̈ Hoşun'un büyük kanunu" diye bahsedilmiş, bunun gibi bașka yerlerde de "dışdaki ùç Hoşun" tâbiri kullanılmıştır.

Buna karşlık bu kanunun ne zamana kadar bütün Haiha Moğolla rında yürürlükte kaldığı meselesi henüz aydınlatılmamıştır. Yalnız Urga Hutuhtu'sunun Sabi'leri yâni 100.000'den fazla insan için bu 1921' kadar asil uygulanan kanunu teşkil etmistir.

IV. Ek'de - Riaz S. 72 v. öt. ye göre - bab başlılarının bir özeti ve. rilmiştir.

7) Kanunun tedvininde rahip sınıfının nüfuzunun büyük olduğu şüphesizdir. Kanunun ilk genis bölïmü hemen hemen tamamiyle rahip sınıfının ve manastırların işlerine tahsis edilmiştir. Ayrıca eldeki hükümleri soğu da böyledir. (bk. IV. ek E.)

8) Anlatulmak istenen Tugetuhan, Tsetsenhan ve Dzasaktuhan Aymaklaridir (Bk. aynı dergi IX. cild, sayn 3-4., S. 243). 


\section{Kesim}

\section{CINLILFRIN MOGOLISTAN ICGIN GIKARMIS OLDUKLARI KANUNLAR}

(I) Daha ilk Mançu hükümdarlar bile yeni uyrukları Moğollar için kanunlar çıkarmışlardı. Bunlar başlangıçta yalnız tẹmoğolistan için çkarılmış olmakla beraber sonradan bunların yürürlük bölgeleri Dışmogolistan't da içine alacak şekilde genişletiimişti. Imparator K'ang-hsi 1696 'da öngidenleri taraftndan çlkarılmış olan bütün bu kanunları bir kitap hâlinde topladı. Ch'ien-lưng zamanında ihtiyaçları hesaba katan Mançu hükûmeti 1789 yılında Moğolistan için yeniden bir kanun kitahı çlkarttı. K'ang-hsi kanununun Dışmoğolistan'da yeni bulunmuş olan bir nushasıyla karşlaştırmanın da gösterdiği gibi bu yeni kanuna K'ang-hsi kanununun hemen hemen bütün hükümleri alınmıştır. Böylece ortaya gözden geçirilmiş ve genişletilmiș bir K’ang-hsi kanunu çımıştır.

V. ek'de 1789 tarihli kanunun Arhimandrit (=baş papaz) Hyakinth (1) tarafindan yapılmıs rusça tercumesine dayanarak metnini veriyoruz. Maddelere ayırma işi de Hyakinth tarafından yapılmıştır. Konumuz bakımından önemli olmiyan ve bilhassa yainız Icmoğolistan'ı ilgilendiren bir sıra hüküm bu arada bizim verdiğimiz metne sokulmamış olđuğu gibi gene incelememiz için az değeri olan bazı hükümlerin de yalniz kısaca muhtevalarinı vermekle yetindik.

(II) Çok geçmeden 1789 tarihli kanunun ihtiyaçlara yetmediği görüldü. 1811'de Li-fan-yuian (sınır bölgesi dairesi) başkanı, imparator Chia-ch'ing'e sunduğu bir raporda sunları tespit ediyordu: “. . . yürür lükte bulunan kanuna alınmamış olan bir sıra suç hakkında zamanla en yüksek makamm karar vermesi gerekmiştir. $\mathrm{Bu}$ ise bakanlığın birçok raporlar hazırlaması bu hususta da bir çok (imparator tarafindan) emir. lerin verilmesi mecburiyetini doğurmuştur. Bu emirler ise genel kanuna henüz eklenmemişler ve böylece henüz yayınlanamamıșlardır." Bundan sonra başkan, Ch'in-lung'un 34 yildir süren hükúmeti sirasında verilmiş olan kararları toplamak ve bunlarn içinden kanun kuvvetinde olan. Iarinı kanuna eklemek müsaadesinin kendisine verilmesini rica etmekte. dir. $\mathrm{Bu}$ işle uğraşmaya bir komisyon memur edildi. Komisyon ise meselenin bu şsekilde hâllini imkânsız bulđu ve imparatorun müsaadesiyle yeni bir kanunun tedvinine girişti. Bunun sonunda 1815 tarihli kanun or.

1) Hyakinth, Haturalar, 2. C., S. 204 v. öt. 
taya çlktı. Bu Mançu hükûmeti tarafindan Moğolistan için çıkarı̣lmı૬ olan son kanundur.

Bu kanunun Mançu'dilinde yazllmıs olan orijinali 67 kitap ihtiva etmektedir ama bunlar bölümiere ayrılmadığı gibi başlık ve numaradan da mahrumdurlar. Bunun 1828'de bir tercümesini yayınlamış olan Lipowtzeff bu tercümede eseri aşağıdaki gibi bölümlere ayırmıştır:

Giris: Li-fan-yüan'in kuruluşu - 6 bab, 56 madde;

1. Bölừm: Medenî hukuk - 21 bab, 494 madde;

2. ". : Askerî kanunlar - 6 bab, 88 madde;

3. " : Ceza hukuku - 20 bab. 191 madde;

4. " : Lamalar hakkında hükümier - $11 \mathrm{bab}, 117$ madde;

5. " : Tibet hakkında hükümler - 13 bab, 66 madde;

6. " : Rusya ile münasebetler - 6 bab, 28 madde.

1815 tarihli kanunun metnini burada vermekten vazgeçtik; çünkił bizi ilgilendiren hususlarda bu kanunda 1789 tarihli kanuna nazaran bir yenilik hemen yok gibidir. Ayrıca biz Moğolistan için Çiniiler'in yasama faaliyetini incelerken daha çok Ch'ien-lung ile yetinmekteyiz.

Her iki kanun da hem łç-hem de Dışmoğolistan'da yürürlüğe girmişlerdir. 